\title{
Trade, Environment and Sustainable Development: What Changed in Doha
}

\author{
Jessica Wilson
}

Environmental Monitoring Group

\section{ABSTRACT}

Agenda 21, the blueprint for sustainable development, adopted at the Earth Summit in Rio de Janeiro in 1992, does not have a chapter dedicated to trade. Yet since 1992, trade has become increasingly important to democracy, human rights, women's rights, economic development, employment and the environment. "Trade and environment" has been identified by many governments and civil society organisations as an important policy issue in preparations for the World Summit on Sustainable Development. At the same time, environment has become a highly politicised word in the world inhabited by trade negotiators. The aim of this paper is to examine whether or not the inclusion of WTO environmental negotiations, as outlined in the Doha Ministerial Declaration, advances or retards sustainable development.

JEL O13, O19, Q32

\section{INTRODUCTION}

Agenda 21, the blueprint for sustainable development, adopted at the Earth Summit in Rio de Janeiro in 1992, does not have a chapter dedicated to trade. Yet since 1992, trade - who trades, how they trade, what they trade and how much they trade - has become increasingly important to democracy, human rights, women's rights, economic development, employment and the environment. "Trade and environment" has been identified by many governments and civil society organisations as an important policy issue in preparations for the World Summit on Sustainable Development. At the same time, environment has become a highly politicised word in the world inhabited by trade negotiators. In November 2001, negotiations on trade and environment in the World Trade Organisation (WTO) were agreed to by Trade Ministers in Doha, Qatar.

The aim of this paper is to examine whether or not the inclusion of environmental considerations in trade agreements advances or retards 
sustainable development. Is the environment simply a new way of protecting northern markets? Or can it be used to advance equity and social justice within and between countries? The specific question that this paper addresses is whether or not including environment in the World Trade Organisation, as outlined in the Doha Declaration, will make it easier or more difficult to achieve development that is sustainable. The paper provides an analytical framework for the debate that outlines clear sustainable development parameters for trade and outlines elements of the ecological and economic crises that need to be addressed. It provides a brief history of how environmental issues have been interpreted in the WTO, culminating with the launch of environmental negotiations in Doha. It evaluates these prescribed negotiations against sustainable development imperatives and examines their implications for other international processes. Finally, it offers some suggestions as to how South Africa should use the environment and trade negotiations to promote sustainable development more effectively.

In this paper, development is used to mean that all people are able to have better lives - be that greater access to health care, more food, better jobs, more able to express themselves creatively, living in confidence instead of fear, etc. Sustainable is used to mean that development can continue and will not be constrained by the earth's natural resources, stock market crashes or conflict; that no person's development happens at the expense of another's - whether or not they are born.

\section{FRAMEWORK FOR ANALYSIS}

One thing that has become apparent this century is that the earth's ecosystems are under enormous pressure and are starting to show significant signs of stress. This is due the pollution that the world population emits, the forests that are cut down, the fish that is harvested, all in excess of the earth's ability to replenish them. A key driver in this behaviour is the way in which nations run their economies. World production is rising, and the firm belief is that this creates jobs and wealth that will contribute to human growth and development. Yet, in producing goods, destruction also takes place, often without the knowledge of the producers. Conventional economic systems provide very poor feedback on their environmental impact. 


\section{The World Trade Organisation (WTO)}

One of the key institutions that manages the economy globally, is the World Trade Organisation (WTO). Its name is misleading; the WTO's agenda is far more comprehensive than just trade rights, intellectual property, international investment flows, government procurement and competition policy are some of the other aspects on which the WTO has developed treaties and which are integral to the global economic system. Being an important regulator in the global economy, the WTO has an impact in many domains - peoples' livelihoods, nature of work, type of education, living environments, etc. Because of this far reaching impact, the question is how the negative aspects of the WTO may be mitigated.

The WTO is not a neutral forum. It has an ideological bias - it is built on the premise that trade liberalisation is inherently good; and an economic bias - it is dominated by a group of economic giants known as the Quad (USA, Canada, EU, Japan). Thus the nature of trade liberalisation is highly uneven. It is not "free" trade, but selective free trade. Developed countries have maintained strong protection on their key (vulnerable) sectors, where developing countries have a comparative advantage. Despite its rhetoric, the WTO is not an organisation that aims to promote human development or greater wealth for poor people. And it certainly has no mechanisms to evaluate whether or not the world's economy is operating within the earth's ability to regenerate itself. In this, it reflects the national economic policy of most countries - that the environment can be cleaned up once sufficient wealth has been created.

There are mechanisms within the WTO to deal with environment and development issues. They are dealt with separately through the Committee on Trade and Environment (CTE) and the Trade and Development Committee. These committees do not bave a negotiating mandate. They seek to clarify and make recommendations on various aspects of trade, environment and sustainable development. South Africa has not been an active member of the CTE, which it sees as low priority, having made very little progress since its inception (Crompton, 2001). A third important structure within the WTO, is the Dispute Settlement Body, which has the sole authority to establish panels to resolve disputes, which normally comprise three members who are senior officials or experts in trade law (FGD, 1998). This mechanism has been strongly criticised by NGOs and developing country governments as being untransparent and undemocratic. Yet the strength of the WTO in enforcing dispute settlement has been one reason why certain groups have demanded the inclusion of labour and environment clauses within the WTO. 


\section{Trade aspects of sustainable development}

There is growing recognition amongst social movements internationally that there are some fundamental contradictions between globalisation, as it has been advanced through institutions such as the WTO, and sustainable development. Whereas globalisation has led to increased inequalities, the commodification of previously untraded goods and the alienation of people from their communities and environments; sustainable development is premised on an economic system that is able to provide for people's needs, whether or not this is done through a market mechanism. It includes considerations of equity, justice, empowerment and environmental integrity. Within the trade regime, there are four key aspects that we need to "get right" if we are to advance sustainable development:

Share the benefits of trade between countries so that terms of trade become equal;

- Bring people back into trade in order to build meaningful economies;

- Incorporate environmental considerations so that trade has a future; and

- Sustainable consumption, thereby orienting production to meet people's needs.

These aspects are seldom considered in current trade policy and practice.

\section{Questioning the dominant trade paradigm}

Trade policy in South Africa as in most other countries, is based on an assumption that there is a direct, causal relationship between trade liberalisation, economic growth, development and sustainable development. The first is a necessary (but not sufficient) condition for the second, which is a necessary (but not sufficient) condition for the third, and so on.

But a conceptual and operational understanding of sustainable development remains weak in national economic ministries and in international economic institutions. Trade policy is not conceived within the framework of sustainable development in South Africa (nor internationally). The nature of the relationship between these components is complex and far from agreed upon. Scoring top marks in the first three (i.e. achieving high levels of trade liberalisation, economic growth and development) does not tell us very much about the fourth component, i.e. whether or not development is sustainable. Likewise economic growth and trade liberalisation do not tell us very much about development. Furthermore, even the link between trade liberalisation and economic growth is starting to be questioned (Halle, 2001). A study produced by the Centre for Economic and Policy Research, found that globally, growth was considerably slower during the $1980-2000$ period of rapid globalisation, than between 1960-1980 (Weisbrot et al., 2000). On average, per capita output 
fell from an 83 per cent growth rate in the earlier period to only 33 per cent growth over the last twenty years. In sub-Saharan Africa, GDP grew by 36 per cent between 1960 and 1980 , whereas it fell by 15 per cent between 1980 and 2000.

\section{ECOLOGICAL DESTRUCTION AND FAILING ECONOMIES: MIRRORS OF THE SAME CRISIS}

There is a strong correlation between some of the environmental concerns and some of the problems in the global economy. Arguments for environmental justice and economic justice stem from a similar analysis of the disjuncture between globalisation and sustainable development. Overproduction, the crisis of capitalism, international competitiveness and decreasing rates of growth have profound implications for how economies are run and how the environment is managed.

Towards the end of the $1960 \mathrm{~s}$, rising unemployment, inflation and falling profits indicated that capitalism was in crisis (Lehulere, 2000). At the same time the depth of the ecological crisis was starting to be recognised. There was an awareness that the life-supporting systems were changing fundamentally, in ways that could be devastating and irreversible. For example, human induced climate changes impacts on where plants can grow and humans can live; ozone layer depletion brings the risk of harmful radiation; destruction of marine resources and pollution of freshwater has devastating effects on people who are dependent on them, and so on.

Overproduction, a common feature of capitalism, is a problem both for the economy and the environment. From a market perspective, new consumers must be found to purchase excess produce. Overproduction in industrial countries has led to an aggressive search for new markets in the South. From an environmental perspective, production should be limited to the ability of natural systems to replenish themselves and process waste. Overproduction tends to result in unnecessary pollution (often toxic or eternal) and excessive use of scarce natural resources, such as wood, water and energy.

Both the ecological and economic crises have resulted in a move towards efficiency and growth in the service sector. These aims appear laudable - fewer resources are used to make the same product or provide the same service. But there are problems with this approach. For example, labour is a key resource that we should not be looking to minimise. In South Africa, production should be labour intensive if we are to have any hope of meeting our reconstruction and development targets. 
Environmentalists have long argued that there are limits to growth. This has been observed in decreasing rates of growth over the past 20 years. Yet the underlying assumption of the WTO is that growth will continue, wealth will increase and will eventually trickle down to poor people who are currently excluded from the economy, and to fixing up environmental damage caused in the pursuit of wealth. This is not what has been observed. Smaller growth rates inevitably lead to greater conflict between capital and labour (Lehulere, 2000). The high concentratoin of wealth among a minority of people indicates that capital is in fact gaining while the poor are being further marginalised, while environmental destruction continues.

This twinning of environmental and economic problems indicates that we should seek an integrated solution.

\section{ANALYSIS}

\section{How is "environment" perceived in the WTO?}

Within the WTO, different constituencies are taking up environmental issues differently. The following table illustrates very broadly the different issues raised by various interest groups during the WTO $3^{\text {rd }}$ Ministerial meeting in Seattle in November 1999. These are the same issues that have been pushed over the past two years and which were important in shaping the trade and environment negotiations launched in Doha, Qatar, at the WTO $4^{\text {th }}$ Ministerial meeting in November 2001.

Endangered species was probably the most visible environmental issue in Seattle. Hundreds of people dressed up as turtles or butterflies, held banners and placards proclaiming that the WTO threatens wildlife. It is probably also the environmental issue most likely to distinguish north from south. In a more nuanced way, northern NGOs are also promoting sustainable consumption, which stems from the understanding that our consumptive lifestyles are one of the biggest threats to environmental integrity. It also acknowledges that people in the North consume much more (and hence impact much more) than people in the South. One of the reasons for reducing consumption in the North, is to allow the South to consume more, resulting in a more equal per capita consumption that remains within the limits of the earth's ability to regenerate natural resources and absorb waste. Where Southem NGOs have articulated environmental concems, they have pushed for environmental justice, based on the understanding that environmental degradation is disproportionately bome by people who are poor and disempowered. 
Table 1 Environmental concerns and position at Seattle

\begin{tabular}{|l|l|l|l|}
\hline $\begin{array}{l}\text { Northern } \\
\text { NGOs }\end{array}$ & $\begin{array}{l}\text { Endangered } \\
\text { Species }\end{array}$ & $\begin{array}{l}\text { Sustainable } \\
\text { Consumption }\end{array}$ & $\begin{array}{l}\text { Fair Trade; } \\
\text { Questioning } \\
\text { expansion of trade }\end{array}$ \\
\hline $\begin{array}{l}\text { Northern } \\
\text { Govern- } \\
\text { ments }\end{array}$ & $\begin{array}{l}\text { Environmental } \\
\text { concerns } \\
\text { equivalent to } \\
\text { market protection }\end{array}$ & $\begin{array}{l}\text { 'Multi- } \\
\text { functionality' of } \\
\text { agriculture }\end{array}$ & $\begin{array}{l}\text { Precautionary } \\
\text { principle }\end{array}$ \\
\hline $\begin{array}{l}\text { Southern } \\
\text { NGOs }\end{array}$ & $\begin{array}{l}\text { No strong voice } \\
\text { on environment }\end{array}$ & $\begin{array}{l}\text { Component of } \\
\text { sustainable } \\
\text { development; vision } \\
\text { of environmental } \\
\text { justice }\end{array}$ & $\begin{array}{l}\text { Questioning export- } \\
\text { led growth }\end{array}$ \\
\hline $\begin{array}{l}\text { Southern } \\
\text { Govern- } \\
\text { ments }\end{array}$ & $\begin{array}{l}\text { No to } \\
\text { environmental } \\
\text { issues }\end{array}$ & $\begin{array}{l}\text { Pro-active on } \\
\text { TRIPS }\end{array}$ & $\begin{array}{l}\text { Article XX } \text { (general } \\
\text { exceptions) sufficient }\end{array}$ \\
\hline $\begin{array}{l}\text { South } \\
\text { African } \\
\text { Government }\end{array}$ & $\begin{array}{l}\text { Premature to } \\
\text { include } \\
\text { environment }\end{array}$ & $\begin{array}{l}\text { Broad } \\
\text { 'development' round }\end{array}$ & \\
\hline
\end{tabular}

Northern governments' interpretation of their environmental constituency is through a very protectionist lens. For example, the USA proposed to liberalise environmental services even though technology transfer obligations are not currently met under the Multilateral Environmental Agreements, which are much more appropriate instruments to deal with genuine environmental concerns, but which the USA have generally not even ratified. Multifunctionality can easily be interpreted as a new way to protect European agriculture. Certain subsidies and support to agriculture will be justified on the basis that agriculture has multiple functions, for example conserving the landscape. Southerm governnients are very cautious about bringing the environment into the WTO because it would be easy to use it to justify protectionist behaviour. One exception is on TRIPS, where African countries are arguing for it to be amended, so that i) no life forms can be patented, and ii) there is proper protection of indigenous knowledge. The South African government has been a strong advocate of a broad development round. From an environmental perspective, this contains some flawed assumptions, namely that i) growth is desirable and can mitigate hidden costs - such as toxic waste or over-fishing - and later, ii) the south can achieve the same standard of living as the north (which unrealistically requires a sixteen-fold increase in resource use and pollution over the next five decades). 
The inclusion of environment into the WTO would link it to the trade agreements so that if there is an environmental infringement, the WTO's dispute settlement mechanism could be invoked. There are a couple of problems with this. The first is an intuitive caution - the countries that are pushing for the inclusion of "environment" do not have a particularly good history of managing it and are certainly consuming more than their fair share of the world's resources. The European Union is particularly strong in pressurising other countries to support its call to make the environment part of WTO agreements. The USA favours the liberalisation of environmental services even though it has not ratified any of the key multilateral environmental agreements. The second concern is that bringing non-trade issues into the WTO would be to introduce them to a forum that is highly biased against small or weak economies; it brings them into a playing field which is dominated by the Quad - a group of four countries comprised of the EU, the USA, Canada and Japan. This would allow economic giants to dictate what is good environmental practice and to sanction those that failed to comply.

These different issues were pushed for different reasons; it is interesting to see how they manifested in the subsequent WTO Ministerial Meeting.

\section{What happened in Doha, Qatar}

Despite strong opposition to the inclusion of negotiations on trade and environment, the WTO $4^{\text {th }}$ Ministerial held in Doha, Qatar from 19-14 November, 2001 stated:

"31. With a view to enhancing the mutual supportiveness of trade and environment, we agree to negotiations, without prejudging their outcome, on:

i) the relationship between existing WTO rules and specific trade obligations set out in multilateral environmental agreements (MEAs). The negotiations shall be limited in scope to the applicability of such existing WTO rules as among parties to the MEA in question. The negotiations shall not prejudice the WTO rights of any Member that is not a party to the MEA in question.

ii) procedures for regular information exchange between MEA Secretariats and the relevant WTO committees, and the criteria for the granting of observer status;

iii) the reduction or, as appropriate, elimination of tariff and non-tariff barriers to environmental goods and services."

Negotiation on fisheries subsidies are agreed to in a separate paragraph, which states: "participants shall also aim to clarify and improve WTO disciplines on fisheries subsidies, taking into account the importance of this sector to developing countries." 
In addition there are some suggestions for pre-negotiations through the Committee on Trade and Environment (CTE) "to give particular attention to:

i) the effect of environmental measures on market access, especially in relation to developing countries, in particular the least-developed among them, and those situations in which the elimination or reduction of trade restrictions and distortions would benefit trade, the environment and development

ii) the relevant provisions of the Agreement on Trade-Related Aspects of Intellectual Property Rights; and

iii) labelling requirements for environmental purposes."

Evaluation environmental negotiations against sustainable development imperatives

This section examines how the negotiations and pre-negotiations agreed to in Doha might contribute to sustainable development, bearing in mind the four key aspects of sustainable development that needs to be addressed in the trade regime:

- Share the benefits of trade between countries so that terms of trade become equal;

- Bring people back into trade in order to build meaningful economies;

- Incorporate environmental considerations so that trade has a future; and

- Sustainable consumption, thereby orienting production to meet people's needs

Table 2 provides a summary of the discussion presented below. 
Table 2 Contribution of environmental negotiations to sustainable development

\begin{tabular}{|c|c|c|c|c|}
\hline & $\begin{array}{l}\text { Equalising trade } \\
\text { terms }\end{array}$ & $\begin{array}{l}\text { People-centred } \\
\text { economies }\end{array}$ & $\begin{array}{l}\text { Environ-mental } \\
\text { considerations }\end{array}$ & $\begin{array}{l}\text { Sustainable } \\
\text { consumption }\end{array}$ \\
\hline \multicolumn{5}{|c|}{ Negotiations launched in Doha, November 2001} \\
\hline $\begin{array}{l}\text { MEA trade } \\
\text { obligations }\end{array}$ & $\begin{array}{l}\text { Possible If rules } \\
\text { are developed and } \\
\text { agreed to, it could } \\
\text { discourage } \\
\text { unilateral action } \\
\text { in the name of } \\
\text { 'environmental } \\
\text { management'. }\end{array}$ & $\begin{array}{l}\text { No The WTO is } \\
\text { an inappropriate } \\
\text { forum to discuss } \\
\text { buman well- } \\
\text { being. The talks } \\
\text { will be technical. }\end{array}$ & $\begin{array}{l}\text { Possible Although } \\
\text { there is a major } \\
\text { loop-hole in that } \\
\text { countries who do } \\
\text { not sign MEAs are } \\
\text { exempt (this } \\
\text { provides an } \\
\text { incentive not to } \\
\text { ratify MEAs) }\end{array}$ & \\
\hline $\begin{array}{l}\text { WTO-MEA } \\
\text { information } \\
\text { exchange }\end{array}$ & \multicolumn{4}{|c|}{$\begin{array}{l}\text { Difficult to assess Information exchange appears neutral, but could have } \\
\text { implications for sustainable development, depending on what actions arise } \\
\text { from the information exchange. These implications could be negative or } \\
\text { positive. }\end{array}$} \\
\hline $\begin{array}{l}\text { Environ- } \\
\text { mental } \\
\text { goods \& } \\
\text { services }\end{array}$ & $\begin{array}{l}\text { No Developed } \\
\text { countries have } \\
\text { comparative } \\
\text { advantage in } \\
\text { environmental } \\
\text { goods and } \\
\text { services. Could } \\
\text { undermine } \\
\text { technology } \\
\text { transfer under the } \\
\text { MEAs. }\end{array}$ & $\begin{array}{l}\text { No There is no } \\
\text { indication that } \\
\text { environmental } \\
\text { services are } \\
\text { inherently more } \\
\text { people-focussed } \\
\text { than any other } \\
\text { traded sector. } \\
\text { Allowing water } \\
\text { to be included as } \\
\text { a service could be } \\
\text { disastrous. }\end{array}$ & $\begin{array}{l}\text { Possible } \\
\text { Environmental } \\
\text { technologies could } \\
\text { lead to more } \\
\text { efficient use of } \\
\text { resources, such as } \\
\text { energy and water, } \\
\text { but liberalisation } \\
\text { will need to be } \\
\text { linked to regulating } \\
\text { overall } \\
\text { consumption. } \\
\text { Allowing water to } \\
\text { be included as a } \\
\text { service could be } \\
\text { disastrous. } \\
\end{array}$ & $\begin{array}{l}\text { Passible There } \\
\text { might be } \\
\text { efficiency } \\
\text { gains per unit } \\
\text { of production, } \\
\text { but it is } \\
\text { unlikely to } \\
\text { address overall } \\
\text { consumption. }\end{array}$ \\
\hline Fisheries & $\begin{array}{l}\text { No An agreement } \\
\text { to reduce fisheries } \\
\text { subsidies would } \\
\text { benefit deve- } \\
\text { loping countries, } \\
\text { if it is not linked } \\
\text { to other trade } \\
\text { agreements. This } \\
\text { positive scenario } \\
\text { is unlikely to } \\
\text { transpire and was } \\
\text { not mandated in } \\
\text { Doha. }\end{array}$ & $\begin{array}{l}\text { No There is no } \\
\text { indication that } \\
\text { negotiations will } \\
\text { consider the } \\
\text { needs of people } \\
\text { dependent on } \\
\text { marine resources } \\
\text { for their } \\
\text { livelihoods. }\end{array}$ & $\begin{array}{l}\text { No An agreement } \\
\text { to reduce fisheries } \\
\text { subsidies would } \\
\text { benefit marine } \\
\text { resources (by } \\
\text { reducing total } \\
\text { catch) but such an } \\
\text { agreement is not } \\
\text { likely and was not } \\
\text { mandated in Doha. }\end{array}$ & $\begin{array}{l}\text { No The } \\
\text { vagueness of } \\
\text { commitment } \\
\text { indicates that } \\
\text { there is no } \\
\text { serious desire } \\
\text { to put fisheries } \\
\text { on a path } \\
\text { where they are } \\
\text { harvested and } \\
\text { consumed in a } \\
\text { sustainable } \\
\text { manner. } \\
\end{array}$ \\
\hline
\end{tabular}


Table 2 continued

\begin{tabular}{|c|c|c|c|c|}
\hline & $\begin{array}{l}\text { Equalising trade } \\
\text { terms }\end{array}$ & $\begin{array}{l}\text { People-centred } \\
\text { economies }\end{array}$ & $\begin{array}{l}\text { Environmental } \\
\text { considerations }\end{array}$ & $\begin{array}{l}\text { Sustainable } \\
\text { consumption }\end{array}$ \\
\hline \multicolumn{5}{|c|}{ Pre-negotiations (discussion at the Committee on Trade and Environment) } \\
\hline $\begin{array}{l}\text { Market } \\
\text { access }\end{array}$ & $\begin{array}{l}\text { No Talks are } \\
\text { aimed at } \\
\text { identifying when } \\
\text { environmental } \\
\text { measures affect } \\
\text { market access. } \\
\text { They are not } \\
\text { negotiations, so } \\
\text { there is no } \\
\text { guarantee that } \\
\text { negative impacts } \\
\text { on market access } \\
\text { will be remedied. }\end{array}$ & $\begin{array}{l}\text { No See previous } \\
\text { box. Market } \\
\text { access talks will } \\
\text { need to look at } \\
\text { impacts on small- } \\
\text { scale producers. }\end{array}$ & $\begin{array}{l}\text { Perhaps If talks } \\
\text { move into } \\
\text { negotiations and } \\
\text { there is } \\
\text { identification of } \\
\text { instances where } \\
\text { reduced trade } \\
\text { restrictions benefit } \\
\text { environment and } \\
\text { development. } \\
\text { Fisheries are an } \\
\text { obvious example of } \\
\text { the potential for } \\
\text { this, yet they are } \\
\text { not included under } \\
\text { this paragraph. } \\
\end{array}$ & $\begin{array}{l}\text { No Increased } \\
\text { trade is the } \\
\text { stated } \\
\text { objective, } \\
\text { which in many } \\
\text { instances } \\
\text { undermines } \\
\text { sustainable } \\
\text { consumption. }\end{array}$ \\
\hline TRIPS & \multicolumn{4}{|c|}{$\begin{array}{l}\text { No If there was serious commitment to amending Article } 27(3) \mathrm{b} \text { to reduce } \\
\text { patent protection and strengthen indigenous rights then terms of trade could } \\
\text { improve, people could be given a more central place, the environment could } \\
\text { be managed better at a local level and production better oriented towards } \\
\text { meeting people's needs. This is so very unlikely to happen, particularly within } \\
\text { the CTE. }\end{array}$} \\
\hline Labelling & $\begin{array}{l}\text { No Likely to } \\
\text { exacerbate } \\
\text { unequal terms of } \\
\text { trade because of } \\
\text { high cost of } \\
\text { implementing } \\
\text { certification } \\
\text { systems. } \\
\text { Certification } \\
\text { standards likely to } \\
\text { be biased towards } \\
\text { the North because } \\
\text { they are more } \\
\text { powerful in WTO } \\
\text { negotiations. }\end{array}$ & $\begin{array}{l}\text { Possible Eco- } \\
\text { labels that take } \\
\text { into account local } \\
\text { conditions could } \\
\text { improve } \\
\text { environmental, } \\
\text { health and safety } \\
\text { conditions for } \\
\text { workers. }\end{array}$ & $\begin{array}{l}\text { Possible Shifting } \\
\text { market demand } \\
\text { away from products } \\
\text { that are } \\
\text { environmentally } \\
\text { damaging is } \\
\text { possible through } \\
\text { eco-labelling. e.g. it } \\
\text { could reduce the } \\
\text { production of blood } \\
\text { diamonds and } \\
\text { tropical timber. }\end{array}$ & $\begin{array}{l}\text { Possible } \\
\text { Qualitative } \\
\text { aspects of } \\
\text { consumption } \\
\text { can be } \\
\text { addressed } \\
\text { through eco- } \\
\text { labels, if they } \\
\text { have integrity } \\
\text { and are } \\
\text { relevant to the } \\
\text { locale in which } \\
\text { they are } \\
\text { applied. }\end{array}$ \\
\hline
\end{tabular}

Share the benefits of trade between countries so that terms of trade become equal

It is unlikely that the negotiations and pre-negotiations outlined in the Doha declaration will help to move the balance of trade in the favour of developing countries. Negotiations on environmental goods and services are particularly 
problematic and are likely to exacerbate unequal terms of trade. South Africa might benefit because it has technological capacity and is by far the most dominant economy in the region. Its GDP accounts for 80 per cent of the total GDP of the Southern African Development Community, SADC (Visser, 2000). Liberalisation of environmental services will favour those who own or can develop the environmental technologies and skills. This could undermine technology transfer commitments under the MEAs in that countries will argue that the market is best placed to deliver technology to developing countries. This is problematic because it will not be aimed at reducing the gap between North and South.

Fisheries have long been the target of developing countries' claims of unfair practices, yet it is clear from Doha that these practices are unlikely to change. Parties commit to "clarify and improve WTO disciplines on fisheries subsidies", which does not imply any commitment to reduction of subsidies or reduced pressure by developed countries for access to Southern fisheries. Furthermore, fisheries agreements are required under the SA-EU Trade, Development Co-operation Agreement (TDCA) and under the Cotonou Agreement (which replaced Lomé as the European Union (EU) - African, Caribbean and Pacific (ACP) agreement). These agreements are "aimed at mutually satisfactory conditions for fishing activities in the ACP states" and state that "the ACP states shall not discriminate against the Community" (Cotonou, 2001). Thus positive steps on fisheries in the WTO could be undermined by bi-lateral and pluri-lateral agreements that are tied to preferential market access.

The prescribed pre-negotiations are equally problematic in sharing the benefits of trade. Labelling tends to be biased against small-producers and against countries that do not have the systems in place to monitor and evaluate production. Thus farmers who use no synthetic pesticides and fertilisers because they can not afford them, will not be considered "organic" because they are unlikely to be able to afford to prove that their production methods are worthy of certification.

Market access should theoretically allow poorer countries greater benefits, although the wording does not imply any compensation for reduced access, merely an identification of its effect.

\section{Bring people back into trade in order to build meaningful economies}

The WTO does not deal very well with human or environment issues because issues of its conviction that the market mechanisms will provide all solutions. Aggregate growth (the ostensible aim of trade liberalisation) is a poor indicator 
of wealth distribution within countries and of who is gaining from economic adjustments. Negotiating issues in an ad hoc manner such as outlined in the Doha Declaration is hardly meaningful; what is required is a holistic overhaul of the system.

Fisheries is an area where trade has really worked against small-scale producers and communities dependent on marine resources for their livelihood. The Doha Declaration fails to resolve or address this. Overcapacity of the European fishing industry is largely responsible for pressure on fisheries in Southerm countries, which has often led to the exclusion of artisinal fishers. Yet there is no commitment in the WTO to reduce EU subsidies, which would go some way towards reducing overcapacity.

There is grave concern about one aspect of the services clause of the negotiations; that is, about what constitutes an environmental service or good. Several countries, including the USA and Canada are pushing strongly to include provision of freshwater as a service (Barlow, 2001). This, together with trends towards privatisation, is likely to have devastating effects on the poor by further excluding them from access to basic services. It would also limit the ability of governments at national and local levels to manage water in a sustainable manner.

The Africa Group have strongly objected to Article 27(3)b of the TRIPS agreement, which allows for the patenting of life forms. Their grounds for concern "do not arise merely from the detrimental consequences, such as for further research (patents over research material in this area may restrict further research), from the concept of patentability (that discoveries do not amount to inventions), the rocketing cost of medicines and the targeting of research towards products for the affluent rather than general public health, or from the doubts over the safety of genetically modified products. They do arise equally from deeply held intuitive values. And if any abuse is to be regulated, excluding their patentability is the point to begin" (Africa Group, 2000). The Doha Declaration is vague about which provisions of TRIPS are relevant to discuss in the CTE, but presumably this Article 27(3)b will be the comerstone of those discussions. Allowing for the patenting of genetic resources takes control over resources away from local communities and from people who have been using them (and often protecting them) for generations.

\section{Incorporate environmental considerations so that trade has a future}

The inclusion of negotiations on trade aspects of Multilateral Environmental Agreements (MEAs) within the WTO could be problematic. Unlike WTO agreements, which form part of a single undertaking, countries can choose 
which MEAs to sign and which to ignore. Likewise with labour conventions. Including negotiations on MEAs that "shall not prejudice the WTO rights of any Mernber that is not a party to the MEA in question" provides an incentive for countries not to ratify MEAs. This includes countries such as the USA, which has yet to sign any of the MEAs arising from the 1992. United Nations Conference on Environment and Development (UNCED).

Liberalising environmental goods and services could benefit the environment through more efficient use of natural resources such as water and energy, as well as use of clean technologies that are less polluting. Yet some of this is already mandated under technology transfer clauses within Agenda 21 and specific MEAs. Agenda 21 states that "when discussing transfer of technologies, the human resource development and local capacity-building aspects of technology choices, including gender-relevant aspects, should also be addressed. Environmentally sound technologies should be compatible with nationally determined environmental priorities." This key aspect of local relevance and people-centred technology could be threatened by shifting the onus to a market based solution that cannot possibly allow for such critical nuances.

Pre-negotiations on labelling need to be carefully conducted, if they are to achieve environment protection, rather than economic protectionism. The costs of certification systems are extremely high (both financially and institutionally) and are therefore biased against developing countries and against small-scale producers. The relationship between eco-labels and sound environmental management is not a given. Eco-labels can provide very useful information to consumers, but this depends on the integrity of the label, the relevance of its standards to local conditions etc.

\section{Sustainable consumption, thereby orienting production to meet people's needs}

The WTO and its agreements are not oriented towards sustainable consumption nor sustainable production. On the contrary, the whole rationale behind trade liberalisation is to increase economic production, with very little regard for the type of production. Consumption is not considered overtly - the underlying assumption being that consumption must also increase to match production. This is not a sound premise from which to direct production towards meeting people's needs.

Of all the aspects of environment proposed in the Doha Ministerial, those relating to environmental goods and services and labelling have the greatest potential to contribute to sustainable consumption. But they could also be 
problematic and the degree to which they are positive will depend largely on the exact terms of their negotiation and the ability of countries to manage them nationally.

Although this Table 2 gives a breakdown of where and how environmental negotiations could contribute to sustainable development, it paints an incomplete picture. Possible benefits are unlikely to be realised unless there are fundamental changes in the way that the WTO operates, i.e. unless it becomes democratic and not biased towards rich countries. Currently benefits are likely to accrue to the powerful countries within the WTO and their interests will dominate. Developing countries only have a limited number of people and resources they can deploy for negotiations. For them to assert their interests seriously in environmental negotiations, they will have to give up other areas of negotiation that are more important to them. These include implementation and assessment of the true impacts of the previous (Uruguay) round of trade negotiations. Thus more equal terms of trade, bringing people back into economies and sustainable consumption are unlikely to be realised. Even the environment will probably not benefit as the negotiators are drawn from the economic ministries and have little concept of how to manage the environment. It will be hard to distinguish genuine environmental concerns from those that are used for protectionism. Moving trade towards sustainable development will only be possible if the voice of all sectors of society are incorporated: government, women, youth, environmental NGOs, labour, business, faith-based organisations, etc.

\section{Implications for other international processes}

It is a strange tum of events that the Doha Ministerial Declaration is being presented as a breakthrough for sustainable development and developing countries. The processes leading to the World Summit on Sustainable Development (WSSD) and the International Conference on Financing for Development have both articulated the need to implement the outcome of Doha (UN Monterrey Consensus; UN Chairman's Paper). This is cause for some alarm given that even the environmental negotiations are unlikely to contribute to sustainable development, as discussed above. It is an indication that political space is being taken from the United Nations and given to the World Trade Organisation, with its exclusive membership and ideological and economic biases, to define critical elements of our path to sustainable development. 


\section{RECOMMENDATIONS FOR PROACTIVE ENGAGEMENT}

The trade model promoted by the WTO does not (and can not) take environmental considerations into account, in a manner that would support sustainable development. Although the WTO preamble pays lip-service to sustainable development, if that were to be reflected in the treaties, it would have led to a very different economic model. The International Institute for Sustainable Development (IISD) argues that setting clear goals for the WTO will provide the necessary framework for a shift towards sustainable development (IISD, 2001). Perhaps, but it is likely to require more than this. A fundamental change in the relationship between different international institutions is required. The WTO needs to fall undet a revised and democratised United Nations system, where checks and balances are in place to ensure that all institutions work towards (and not against) the international declaration of human rights and the myriad of other agreements that have been signed to bring peace, stability, dignity and sustainable development to all people The WTO and its agreements must take their place with other international institutions and agreements, fitting into a broader system of democratic global governance that needs to be in place to manage the global commons and the increasing interaction between people across the world.

It is alarming to realise that although developing countries are the least destructive of the global environment, they are paying the most for its protection. This is likely to be exacerbated as more and more things are brought into the market system - biodiversity, indigenous culture, traditional knowledge, etc. South Africa and other developing countries should take a strong stance against expanding the list of what is considered an environmental service in the WTO. Water should not be included. Instead, MEAs should be used to give proper (non-monetary) value to Southern resources that are globally significant (clean air, forests, water, etc.). This value should be used to benefit the poor who are highly dependent on those resources.

Recognition of the relationship between people and their environment is critical if we are to move towards more people-centred economies. This would lead to a person's right to choose and have control over their local resources. Commodification of resources is likely to undermine this, as local people will be competing with far bigger interests for resource use and management. It is therefore important that governments do not give up their responsibility to local development by placing more and more goods and services into the domain of the unregulated global economy.

Sustainable consumption is one of the most critical objectives to come out of Agenda 21. Yet it will not be achieved if trade liberalisation remains a goal in 
itself. Clear national objectives need to be set for trade to reorientate it as a tool for sustainable development. This is likely to mean that there will be less trade and that economies will shift towards greater local production and consumption.

\section{CONCLUSION}

Bringing environment into the WTO is risky for four reasons. Firstly, there is an uneven playing field, which disadvantages developing countries. Secondly, trade is not designed to promote sustainable development. Thirdly, there are numerous processes happening outside the WTO that could be compromised if environment becomes a focus of trade negotiations within the WTO. And fourthly (as developing countries continue to point out), there are huge opportunity costs in engaging in environmental negotiations, before issues that are critical to developing countries have been addressed. These include implementation and the assessment of the true impact of the Uruguay Round.

The way in which environment has been included in the WTO provides greater advantage for developed than developing countries. The agenda for negotiations on trade and environment outlined in the Doha Declaration is biased against developing country interests. There is some room for small gains, but taking a pro-active stance needs to be weighed up against the opportunity cost of reducing focus on other key aspects of WTO negotiations. One example would be for developing countries to be pro-active in identifying where the elimination of trade restrictions and distortions would benefit trade, the environment and development. This could become the basis of their negotiating position and a prerequisite to discussions on issues that are less beneficial, such as ecolabelling. Developing countries need to stand firm about not expanding environmental negotiations to areas which would be detrimental to poor people. This includes keeping water out of negotiations on services and insisting that life-forms are not patented.

The Doha Ministerial Declaration entrenches the WTO's commitment to export-led growth outside a framework of sustainable development. It takes political space away from the United Nations and has infiltrated important international processes with its unsustainable model of economic development. Yet, because rapid globalisation goes fundamentally against sustainable development and people's values, it will continue to hit barriers and be opposed by people for economic, environment, social and human rights reasons. The question of "trade and environment" is not going to go away, but needs to be dealt with outside of the WTO. Within South Africa we need to have a much better understanding of what it means and how to deal with it. This will require enhancing public debate through active engagement between government, 
business, labour and non-profit civil society organisations.

\section{REFERENCES}

1 AFRICA GROUP, (2000) Draft Submission on Article 27.3b to the TRIPS Council, September.

2 COTONOU AGREEMENT (2000).

3 CROMPTON, S. (2001) Interview with the author as part of the DEAT review of Agenda 21.

4 FGD (1998) "Understanding the WTO: Implications and Possibilities for the South", FGD Occasional Paper, No. 13.

5 IISD (2001) "What's it All For? Setting Clear Goals for the World Trade Organisation" (WTO), IISD Viewpoint, August.

6 LEHULERE, O. (2000) "The Evolution of South Africa's Economic Policy", Presented at AIDC-EMG Mobilisation Against Globalisation Workshop, 29-31 May 2000, Johannesburg.

7 HALLE, M. (2001) "International Institute for Sustainable Development", discussion at a ISD/TRALAC Seminar on Trade and Sustainable Development, August, Stellenbosch.

8 UNITED NATIONS (2002) "Monterrey Consensus", Draft Outcome of the International Conference on Financing for Development, 30 January, A/AC.257/L.13, New York.

9 UNITED NATIONS (2002) "Chairman's Paper", Second Session of the Preparatory Committee for the World Summit on Sustainable Development, 8 February, New York.

10 WEISBROT, M., ROBERT, N. \& JOYCE, K. (2000) "The Emperor has No Growth: Declining Economic Growth Rates in the Era of Globalisation", Centre for Economic Policy Research Paper, www.cepr.net

11 WILSON, J. (2001) "Trade, Environment and Sustainable Development", Chapter for the South African Department of Environmental Affairs and Tourism National Review of Agenda 21.

12 WORLD TRADE ORGANISATION (2001) Ministerial Declaration, WT/MIN(01)/DEC/W/1, 14 November, Doha. 